\title{
Penerapan AJAX dalam Aplikasi Mobile Berbasis Web Untuk Meningkatkan Efisiensi Bandwidth
}

Implementing AJAX in Web-based Mobile Application in Order to Imprve Bandwidth Efficiency

\author{
Tony Wijaya \\ Jurusan Sistem Informasi STMIK Pontianak \\ Jl. Merdeka No. 372 Pontianak, Kalimantan Barat \\ E-mail: mail.tonywijaya@gmail.com
}

\begin{abstract}
Abstrak
Teknologi mobile dan Internet sudah bukan merupakan sesuatu yang mahal. Sebagian besar pelaku bisnis di Indonesia sudah memiliki smartphone yang memiliki koneksi Internet. Penulis melihat fakta ini sebagai kesempatan untuk merekayasa aplikasi mobile berbasis web yang dapat diakses dengan smartphone merk apapun yang memiliki koneksi Internet. Namun mengingat harga kuota Internet yang masih cukup mahal di Indonesia, maka penulis menerapkan Asynchronous JavaScript And XML (AJAX) dalam pengembangan aplikasi ini. Jurnal ini akan menguraikan secara jelas tentang bagaiman AJAX dapat menghemat bandwith sehingga aplikasi web mobile yang dihasilkan tidak menguras kuota Internet para pemakainya. Perancangan program pada penelitian ini menggunakan metode Agile dengan pendekatan Scrum. Pengujian dilakukan dengan metode black-box untuk membandingkan kapasitas bandwidth sebelum dan sesudah penerapan AJAX pada aplikasi web mobile. Dengan adanya pembuktian efisiensi bandwith ini, diharapkan para pengembang situs web dan aplikasi web dapat mempertimbangkan untuk menerapkan AJAX pula di dalam aplikasi mereka sehingga dapat menguntungkan para pengunjung situs ataupun para pemakai aplikasi web.
\end{abstract}

Kata kunci: Asynchronous JavaScript And XML, AJAX, efisiensi bandwith

\begin{abstract}
Mobile and Internet technology is not more an expensive thing. Largely part of Indonesian businessmen already have smartphones connected to the Internet. Writer sees this fact as a opportunity to develop a web-base mobile application which can be accessed through any smartphone brands connected to the Internet. But given the price of Internet quota is still relatively expensive in Indonesia, so the writer implement Asynchronous JavaScript And XML $(A J A X)$ in the development process. This journal will describe in depth how AJAX can increase efficiency of bandwith so that the mobile web application does not drain much of user's Internet quota. Agile software development methodology with Scrum approach is used in developing this application. Black-box testing is done to compare both bandwidth capacity exposed before and after implementation of AJAX. With this proven bandwith efficiency, writer hope that website and web application developers can also consider implementing AJAX in their applications so that it can give benefit for the site visitors or web application users.
\end{abstract}

Keywords: Asynchronous JavaScript And XML, AJAX, bandwith efficiency.

\section{PENDAHULUAN}

Berdasarkan data dari Kementerian Komunikasi dan Informatika yang menyatakan bahwa pertumbungan smartphone di Indonesia sangat pesat, bahkan diperkirakan pada tahun 2018 akan mencapai lebih dari 100 juta pengguna aktif [1], maka dengan jumlah itu akan menempatkan Indonesia di peringkat ke-4 setelah Cina, India, dan Amerika. Tentunya dengan 
angka ini, Indonesia menjadi target bagi para manufaktur smartphone di dunia untuk menyuplai hasil produk mereka. Sebut saja beberapa merk smartphone yang sudah beredar di Indonesia seperti Asus, Lenovo, Samsung, Oppo, Vivo, dan masih banyak lagi merk-merk lainnya. Banyaknya merk yang beredar dan membanjirnya stok smartphone menunjukkan bahwa Indonesia merupakan pangsa pasar yang baik bagi smartphone.

Fakta ini sangat menarik perhatian penulis untuk memanfaatkannya sebagai sarana untuk meningkatkan produktivitas para pemakai. Lebih khususnya penulis menargetkan para manager perusahaan untuk memaksimalkan teknologi mobile ini. Penulis ingin merekayasa sebuah aplikasi web untuk mobile yang dapat menampilkan laporan laba-rugi kotor bagi para manager, dari manapun mereka mengaksesnya.

Faktor yang menjadi bahan pertimbangan penulis dalam merancang aplikasi mobile berbasis web ini adalah faktor bandwidth. Seperti kita ketahui bahwa aplikasi berbasis web akan selalu memuat seluruh isi halaman setiap kali berpindah halaman web, mulai dari kop (header), gambar-gambar, menu, isi, dan footer-nya. Belum lagi ada file-file pembantu di belakang layar seperti JavaScript dan Cascading Style Sheet (CSS). Tidak seperti aplikasi Android native yang hanya memuat isi dari aplikasi, sedangkan file-file pembantu seperti gambar-gambar, header, footer, dan lain-lain sudah disalin ke dalam smartphone sehingga waktu muat data lebih cepat dan lebih menghemat kuota Internet. Oleh karena itu, penulis mencoba meningkatkan efisiensi bandwidth pada aplikasi mobile berbasis web ini dengan menerapkan Asynchronous JavaScript And XML (AJAX).

Fitur pada aplikasi mobile berbasis web dalam penelitian ini adalah laporan laba-rugi kotor. Laporan laba-rugi kotor merupakan laporan laba-rugi yang hanya menampilkan hasil kalkulasi antara harga penjualan dengan harga pokok penjualan. Segala beban dan biaya selama periode akuntansi tidak dimasukkan [2]. Berbeda dengan laporan laba-rugi standar, laporan laba-rugi kotor bisa diakses kapan saja tanpa menunggu akhir periode akuntansi. Informasi inilah yang sangat diperlukan para manager untuk dapat mengambil keputusan bisnis dalam waktu yang lebih singkat.

Arsitektur yang digunakan oleh penulis dalam merancang aplikasi ini adalah arsitektur web. Arsitektur web menganut sistem 3 layer yaitu client, server, dan basis data. Di sisi client, JavaScript masih bertahan sebagai bahasa yang paling dominan [3]. Dengan Asynchronous JavaScript and XML (AJAX), penulis dapat mempercepat waktu muat data karena tidak perlu berganti halaman. Di sisi server penulis menggunakan web service. Dengan web services layanan dan aplikasi dapat digunakan ulang, dan memungkinkan terjadinya pertukaran data antar platform yang berbeda [4]. Web service berisi logika bisnis dari aplikasi dan memiliki akses ke layer terakhir yaitu basis data.

Tujuan penelitian ini adalah untuk mempublikasikan cara penerapan AJAX supaya dapat meminimalkan penggunaan bandwith pada aplikasi mobile berbasis web. Selain itu, penulis juga mendedikasikan aplikasi ini bagi para manager yang memerlukan akses ke laporan laba-rugi kotor melalui smartphone mereka. Fitur utamanya adalah laporan laba-rugi kotor. Pengujian dilakukan dengan cara membandingkan penggunaan bandwidth sebelum dan sesudah penerapan AJAX.

\section{METODE PENELITIAN}

Perancangan perangkat lunak dalam penelitian ini adalah menggunakan metode Agile Software Development yang merupakan kerangka konseptual untuk mengembangkan perangkat lunak yang memperkenalkan beberapa tahapan perulangan (iterasi) selama siklus hidup sebuah proyek [5]. Metode ini memiliki karakteristik ringan, skala kecil hingga menengah, kebutuhan (requirement) yang samar dan/atau sering berubah, perancangan yang sederhana, hingga sistem yang minimal untuk menyelesaikan proyek. Setiap programmer yang menggunakan metode ini menjunjung nilai berupa:

M - engedepankan individu dan interaksi daripada proses dan alat

- Mengedepankan perangkat lunak yang berfungsi sesuai kebutuhan daripada dokumentasi yang lengkap 
- engedepankan kolaborasi dengan pelanggan daripada negosiasi kontrak

M - engedepankan respon terhadap perubahan daripada mengikuti rancangan

Scrum merupakan metodologi perancangan perangkat lunak dengan pendekatan iteratif dan inkremental untuk menyaring hal-hal yang dapat diprediksi dan mengontrol kerusakan akibat kesalahan rancangan awal [6].

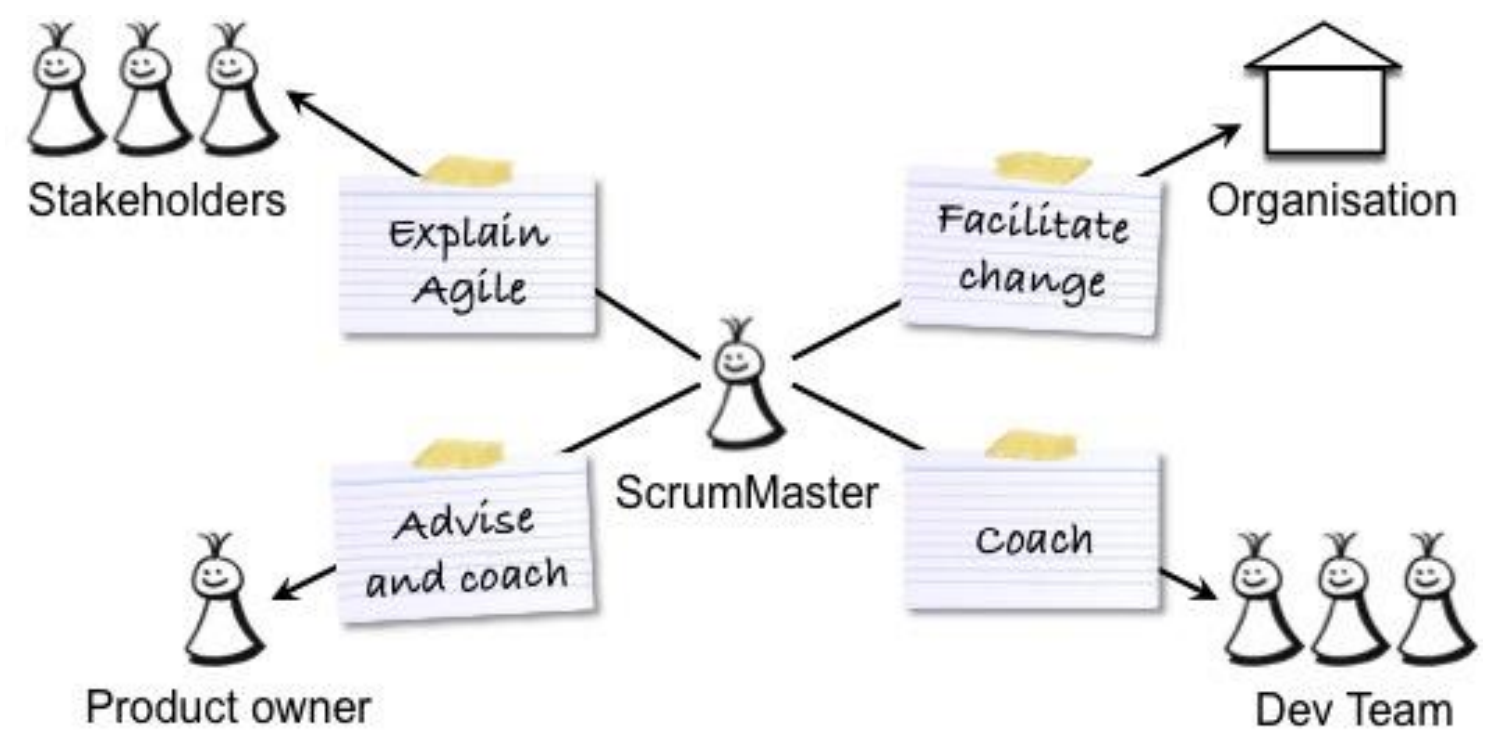

\section{Gambar 1. Fungsi-fungsi Scrum}

Dalam kerangka ini diperlukan 3 (tiga) fungsi penting:

1. Product Owner (PO) atau pemilik produk, merupakan seorang profesional yang memiliki pengetahuan yang mendalam mengenai produk yang akan direkayasa.

2. Scrum Team atau tim scrum, yang beranggotakan indvidu-individu yang mampu mengoranisasikan dirinya sendiri dan merupakan sebuah tim multi-fungsi.

Scrum Master, adalah orang yang bertanggung jawab untuk mengarahkan tim Scrum supaya bekerja menuju arah dan tujuan yang benar dan mengatasi semua rintangan dan

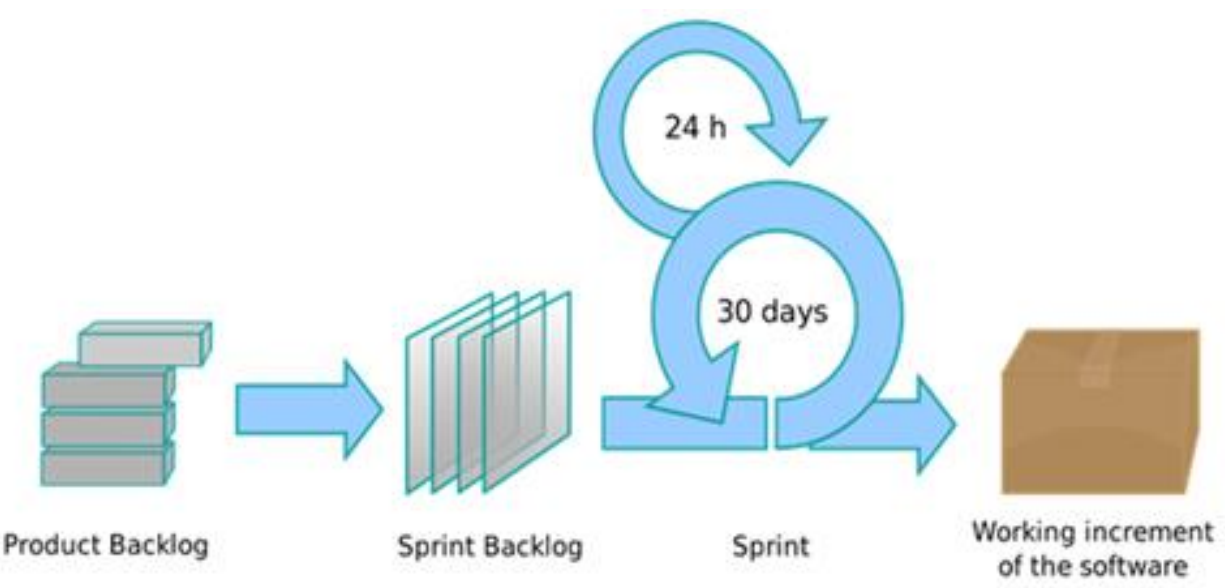

halangan yang dapat mempengaruhi kinerja mereka.

Ketiga fungsi ini bekerja dalam proses pengembangan yang konstan dan lingkaran interaksi yang disebut Sprint. Sprint merupakan kegiatan pengembangan untuk mencapai tujuan kecil (yang dipecah-pecah dari tujuan utama) yang biasanya menggunakan waktu 2-4 minggu, yang disebut TimeBox. Di dalam sebuah Sprint, semua kebutuhan-kebutuhan (requirements) 
untuk mencapai tujuan kecil tersebut disebut dengan Backlog of the Product dan biasanya didefinisikan oleh PO. Pada awal Sprint, tim akan mendefinisikan Backlog of the Product dan kemudian mulai bekerja sehingga pada akhir Sprint, tim sudah menyelesaikan tujuan kecil tersebut untuk ditunjukkan kepada pelanggan (client). Tahapan dalam Scrum dapat dilihat pada gambar 2.

Microsoft Visual Studio merupakan sebuah Integrated Development Environment (IDE) dari Microsoft. IDE ini digunakan untuk mengembangkan program komputer pada sistem operasi Windows, Linux, Android, maupun IOS. Arsitektur aplikasi yang didukung adalah situs web, aplikasi web (offline), web service, plug-in, ekstensi dan aplikasi desktop [7]. Aplikasi di sisi client menggunakan arsitektur berbasis web dengan teknologi ASP.NET yang dirancang, dikode, dan diuji menggunakan Visual Studio 2015. Bahasa pemrograman yang digunakan adalah bahasa C\# dan dikompilasi untuk .NET Framework versi 4.5 yang dijalankan pada Internet Information Services (IIS). ASP.NET adalah framework aplikasi web di sisi server yang bersifat open-source yang dirancang untuk pengembangan web dalam menghasilkan halaman web dinamis. ASP.NET dikembangkan oleh Microsoft untuk memungkinkan pemrogram membangun situs web dinamis, aplikasi web dan web service [8]. Dengan IDE yang sama, penulis merekayasa web service di sisi server menggunakan teknologi Windows Communication Foundation (WCF) yang merupakan kerangka kerja untuk membangun aplikasi berorientasi layanan (Service-Oriented Architecture / SOA) [9].

Untuk merekayasa web mobile di sisi client, diperlukan Asynchronous JavaScript and XML (AJAX). Visual Studio secara default belum mendukung AJAX secara penuh. Oleh karena itu diperlukan ekstensi tambahan yaitu AJAX Control Toolkit yang dikembangkan oleh DevExpress. AJAX Control Tookit merupakan library yang bersifat open source untuk mengembangkan situs web dengan ASP.NET [10].

Basis data yang digunakan untuk adalah basis data MySQL. MySQL merupakan Relational DataBase Management System (RDBMS) yang dapat digunakan untuk asplikasi berbasis web, cloud, mobile dan aplikasi embedded [11]. Sedangkan GUI tools yang digunakan untuk mengelola basis data adalah MySQL Workbench, yaitu merupakan alat grafis terpadu bagi arsitek basi data, pengembang aplikasi, dan administrator basis data. Aplikasi ini menyediakan fitur pemodelan data, pengembangan SQL, dan alat administrasi yang lengkap untuk konfigurasi server, administrasi pemakai, backup, dan lain-lain [12].

Pada Bab 3 terdapat beberapa jargon yang perlu penulis jelaskan yaitu JSON, CSS, dan XHTML. JSON singkatan dari JavaScript Object Notation, yang merupakan format pertukaran data yang sangat sederhana dan ringan [13]. JSON mudah dibaca dan ditulis oleh manusia, mudah diuraikan maupun dihasilkan oleh mesin (komputer). JSON merupakan bagian dari bahasa pemrograman JavaScript - Standar ECMA-262 3rd Edition - December 1999. Format yang digunakan adalah format teks yang benar-benar tidak bergantung pada bahasa pemrograman apapun namun menggunakan konvensi yang familiar bagi pemrogram seperti bahasa C, termasuk C, C ++, C\#, Java, JavaScript, Perl, Python, dan banyak lagi bahasa pemrograman lainnya. Keuntungan ini ini menjadikan JSON sebagai bahasa pertukaran data yang ideal. CSS singkatan dari Cascasding Style Sheet, yaitu sebuah style sheet yang menggambarkan bagaimana elemen-elemen HTML akan ditampilkan pada layar [14]. CSS dapat memberikan efisiensi kerja dan meminimalkan ukuran halaman web karena dapat memformat banyak halaman web sekaligus. Untuk melakukannya, biasanya syntax CSS disimpan dalam file terpisah dengan ekstensi *.css. XHTML dapat diartikan secara sederhana yaitu HTML yang ditulis dalam format XML [15].

\section{HASIL DAN PEMBAHASAN}

Sesuai penerapan metodologi Scrum, maka penulis membagi proyek ini ke dalam 4 kali Sprint:

M 1. erekayasa web service (1 minggu).

M 2. erekayasa web mobile di sisi server (3 hari).

M 3. erekayasa web mobile di sisi client (3 hari). 
M 4. enggabungkan keempat hasil di atas dan melakukan pengujian (1 minggu).

Sebelum memulai pembahasan untuk setiap Sprint, penulis menyajikan diagram Use Case terlebih dahulu untuk menjelaskan pemakai yang akan memakai sistem ini. Diagram dapat dilihat pada gambar 2. Pada gambar tersebut dapat dilihat bahwa web mobile yang akan direkayasa bukan merupakan bagian dari sistem informasi dagang yang sudah dimiliki oleh perusahaan. Akan tetapi sumber datanya diambil dari basis data perusahaan tersebut. Jadi pengembangan sistem ini tidak akan mempengaruhi sistem informasi dagang yang sudah ada. Oleh karena itu, penulis tidak memasukkan tahap merancang basis data pada sprint di atas. Karena basis data sudah ada dan penulis tinggal memanfaatkan data yang telah diinput oleh fakturis. Pada gambar 3 juga dapat dipastikan bahwa aplikasi mobile ini hanya diperuntukkan bagi manager perusahaan. Fakturis dan bagian purchasing tidak memiliki wewenang untuk mengakses aplikasi ini.

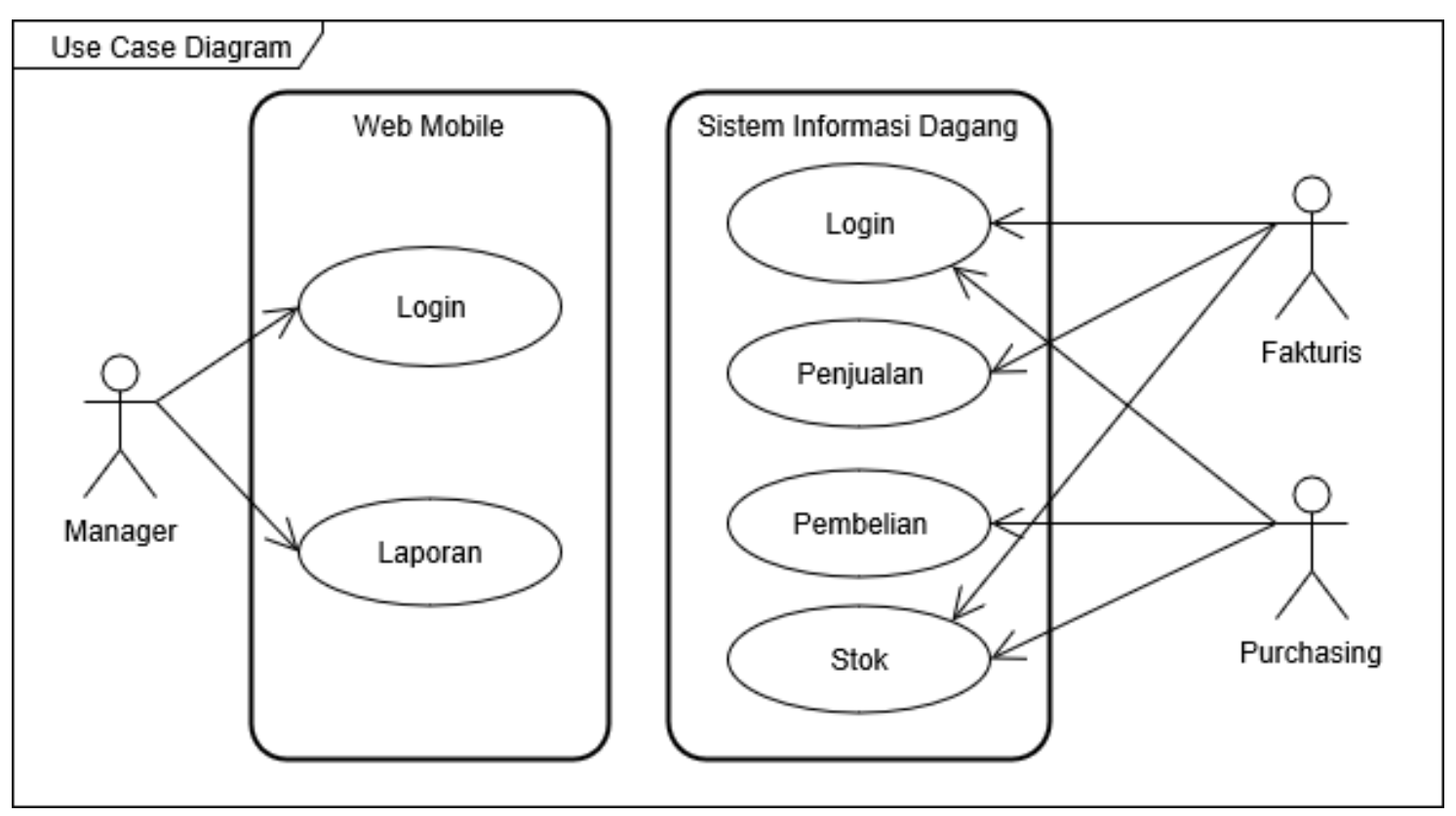

\section{Gambar 3. Use Case Diagram}

Sprint ke-1 yaitu merancang web service yang merupakan backend dari sistem yang akan dibangun. Web service pada aplikasi web mobile ini bertindak sebagai backend yang melayani permintaan dari ASP.NET. Jadi ASP.NET tidak langsung berhubungan dengan basis data MySQL, tetapi melewati web service.

Web service berisi class yang mengakses basis data MySQL dan memformat data dalam bentuk DataSet. DataSet akan dikirimkan kepada ASP.NET untuk diproses lebih lanjut. Tabel-tabel basis data yang dipakai untuk kebutuhan laporan laba-rugi kotor berikut hubungan antar tabel-tabelnya diperlihatkan pada gambar 4. 


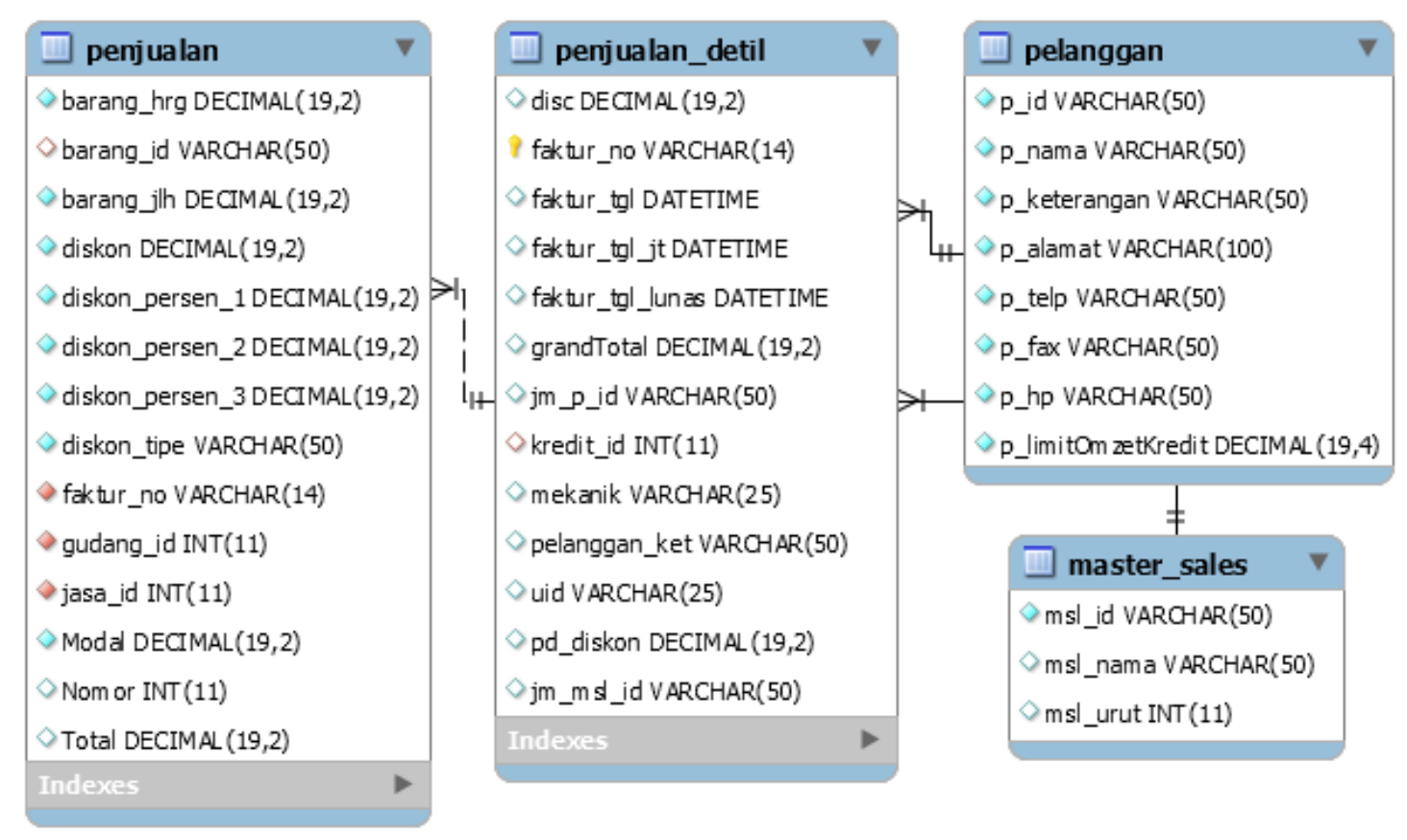

\section{Gambar 4. Diagram basis data Sistem Informasi Dagang}

Web service memiliki tugas mengambil data dari basis data di atas dan melakukan logika bisnis (business logic) yang diperlukan, kemudian mentransfer ke web ASP.NET dalam format DataSet. Kode program dibagi menjadi 2 class utama yaitu Penjualan dan Pemakai. Class Penjualan berisi kode program C\# (.NET Framework 4.0) untuk mengambil data penjualan yang berisi harga jual dan modal. Dari kedua kolom ini akan dihitung dan selisihnya adalah laba kotor. Class Pemakai berisi logika bisnis yang diperlukan untuk proses otentikasi ( $\log$ in). Di dalam class ini password pemakai akan di-hash dengan MD5, baru kemudian dicocokkan dengan nilai password di dalam basis data. Perlu diketahui bahwa nilai password di dalam basis data sudah di-hash supaya tidak dapat dibaca oleh hacker.

Setelah selesai dibuat, kedua class di atas kan diberi interface sehingga dapat dipublikasikan menjadi web service. Pemberian interface diperlukan supaya fungsi-fungsi yang ada di dalam kedua class tersebut dapat diakses dengan open standard, artinya dapat diakses oleh semua bahasa program. Class diagram dapat dilihat pada gambar 5.
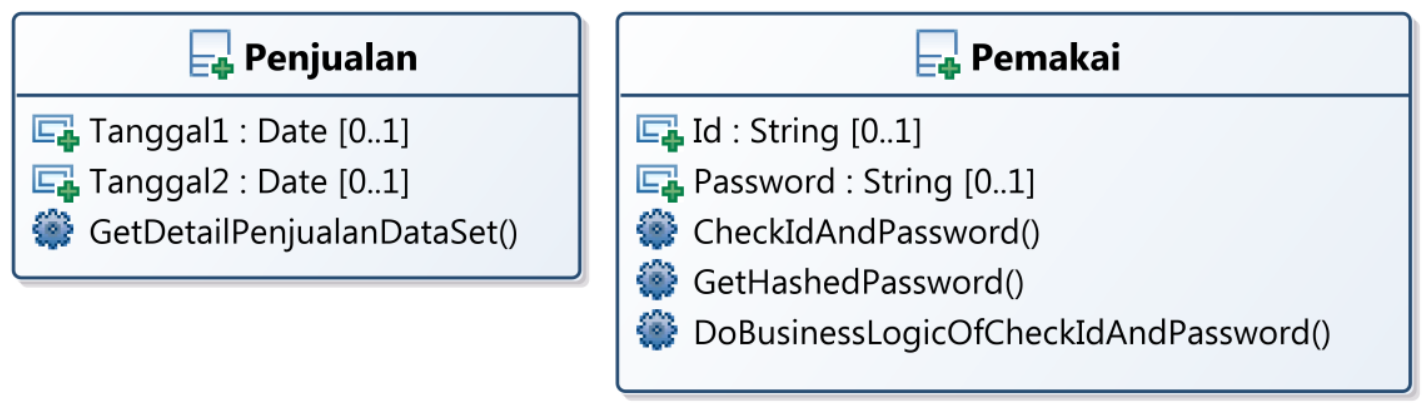

\section{Gambar 5. Class Diagram Sistem Informasi Dagang}

Pada gambar 5, dapat dilihat bahwa class Penjualan memiliki fungsi GetDetailPenjualanDataSet() dan 2 property yaitu Tanggal1 dan Tanggal2. Keduanya memiliki tipe data Date. Tanggal1 dan Tanggal2 merupakan parameter yang dibutuhkan oleh fungsi GetDetailPenjualanDataSet supaya dapat mengambil data laporan laba-rugi kotor dari basis data. Penulis menyajikan activity diagram pada gambar 5 yang dapat menjelaskan secara rinci mengenai algoritma di dalam fungsi tersebut. Class Pemakai memiliki 2 property yaitu Id dan Password. Kedua property ini digunakan oleh 3 fungsi yaitu CheckIdAndPassword(), 
GetHashedPassword(), dan DoBusinessLogicOfCheckIdAndPassword(). Fungsi yang dipanggil oleh client hanya 1 yaitu DoBusinessLogicOfCheckIdAndPassword. Fungsi ini akan memanfaatkan kedua fungsi lain dalam tugasnya. Penulis memisahkan tugas yang berbeda ke dalam fungsi yang berbeda supaya mudah untuk dibaca dan dikembangkan nantinya. CheckIdAndPassword merupakan fungsi yang dipakai untuk memeriksa apakah Id dan Password yang diinput oleh pemakai sudah cocok. Sedangkan fungsi GetHashedPassword merupakan fungsi untuk melakukan mengacak password yang berupa teks biasa menjadi hash yang tidak dapat didekripsi kembali.

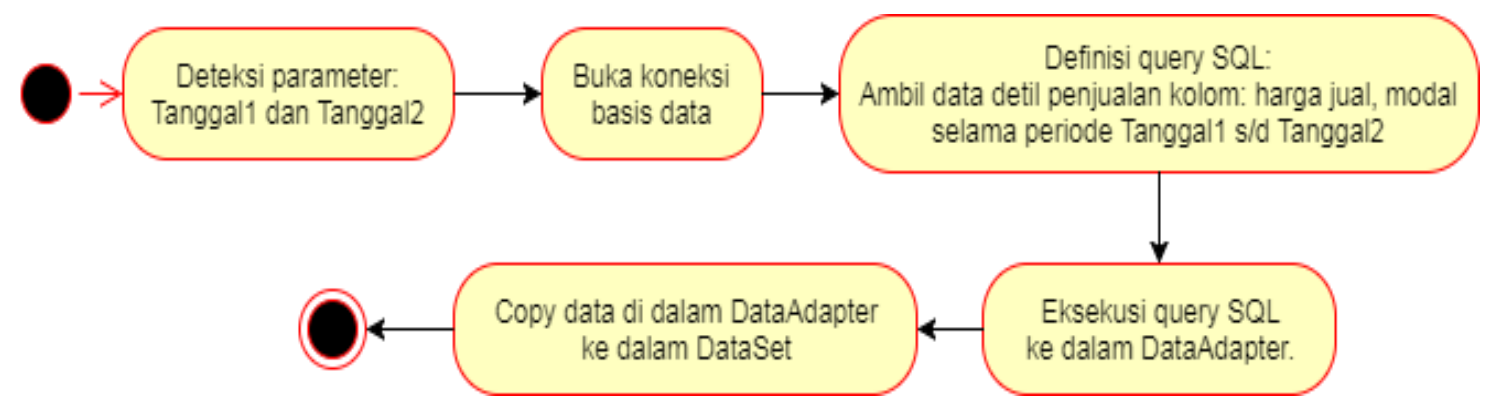

Gambar 6. Activity Diagram Pengambilan DataSet Laporan Laba Rugi Kotor

Sprint ke-2 merupakan kegiatan merekayasa server web mobile dengan teknologi ASP.NET. Server web mobile tidak memiliki wewenang untuk mengakses basis data secara langsung, tetapi memiliki wewenang untuk mengakses web service yang sudah dibuat pada sprint ke-1. Server web mobile bisa diimplementasikan pada server yang berbeda dengan web service apabila diperlukan, supaya bisa mengelola akses dari user yang banyak. Hal ini akan dapat mencegah terjadinya hang pada web service ataupun basis data.

Sprint ke-3 ialah kegiatan merekayasa web mobile di sisi client dengan menggunakan teknologi AJAX. JavaScript bukan merupakan sebuah hal yang baru dalam pemrograman web. Namun Asynchronous JavaScript and XML (AJAX) sedikit berbeda dengan JavaScript standar. Perbedaan JavaScript standar dan AJAX dapat dilihat pada tabel 1.

Tabel 1. Perbedaan JavaScript Standar dan AJAX

\begin{tabular}{|l|c|c|}
\hline & JavaScript Standar & AJAX \\
\hline Akses ke sisi server & Tidak & Ya \\
\hline Manipulasi komponen HTML & Ya & Ya \\
\hline Tipe Proses & Sinkronus & Asinkronus \\
\hline Dukungan browser & Semua browser & Microsoft Edge, Google \\
& & Chrome, Internet Explorer \\
& & 5.5+, Mozilla Firefix 2+, \\
& & Opera 9+, Safari 2+ \\
\hline
\end{tabular}

Tampilan halaman web yang menggunakan AJAX tidak terlalu berbeda dengan halaman web yang menggunakan JavaScript standar. Perbedaan tersebut baru terlihat ketika halaman web melakukan akses ke server, misalnya menampilkan data penjualan. Pada halaman web konvensional, data penjualan akan ditampilkan setelah berpindah halaman. Artinya, browser mengirimkan permintaan (request) ke server, kemudian bahasa pemrograman di sisi server akan memproses request tersebut dengan cara mengambil data dari basis data, memproses HTML, kemudian mengirimkan kembali hasilnya kepada browser dalam bentuk halaman web yang baru. Tetapi dengan AJAX, JavaScript mengirimkan permintaan kepada web 
service.

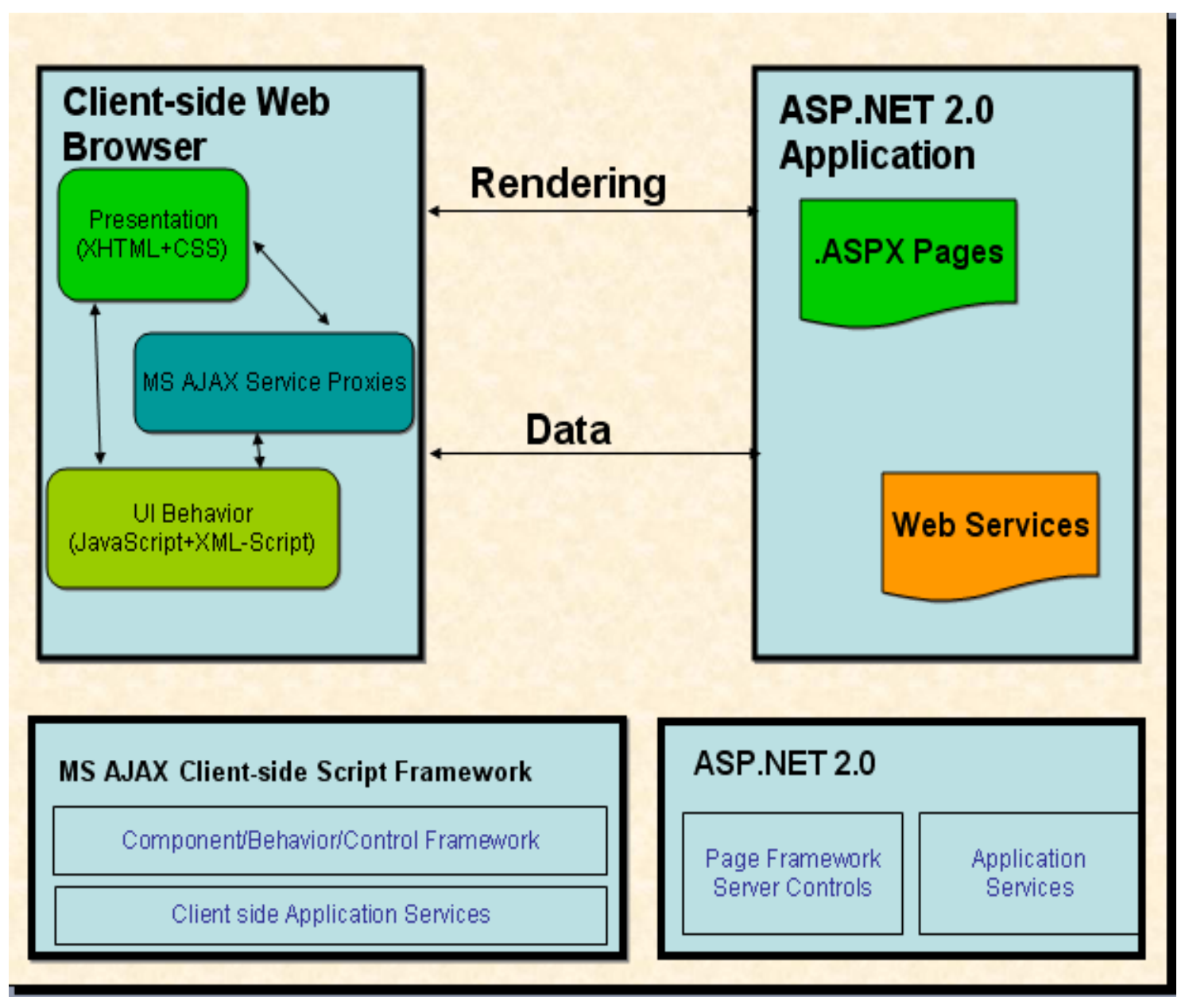

Gambar 7. Arsitektur Web dengan AJAX dan ASP.NET

Di sisi web service, bahasa pemrograman akan memproses request tersebut dengan cara mengambil data dari basis data, kemudian mengirimkan hasilnya dalam format JSON. Selanjutnya, pada browser, AJAX akan memproses data JSON tersebut dalam mengupdate HTML pada halaman web yang sama. Jadi tidak perlu berpindah ke halaman web yang baru. Proses ini tentunya lebih menghemat bandwidth dan overhead dalam pemrosesan data. Dengan demikian, secara performa dan efisiensi, AJAX lebih unggul daripada sistem web konvensional. Pertukaran data antara AJAX dan web service menggunakan format JSON. Arsitektur web mobile yang dirancang dengan AJAX di sisi client dan ASP.NET di sisi server dapat dilihat pada gambar 7.

Pada sisi client yaitu sebuah browser, presentasi utama dihadirkan oleh XHTML dan CSS. Sementara untuk penanganan event ada JavaScript yang biasanya dituliskan secara embedded dalam file HTML. Yang berbeda di sini adalah kehadiran AJAX yang bisa berkomunikasi secara asinkronus dengan ASP.NET di sisi server. ASP.NET di sini tidak bertindak sebagai web service, melainkan sebagai backend bagi web mobile. Di dalam script ASP.NET terdapat fungsi yang mengakses ke web service yang berada pada tier yang berbeda. Pada gambar 1 tidak dijelaskan mengenai tier web service. Tier web service akan dibahasa setelah selesai bagian client.

Proses atau langkah-langkah teknis dalam menampilkan laporan laba-rugi kotor dengan AJAX dapat dilihat pada sequence diagram pada gambar 8. 


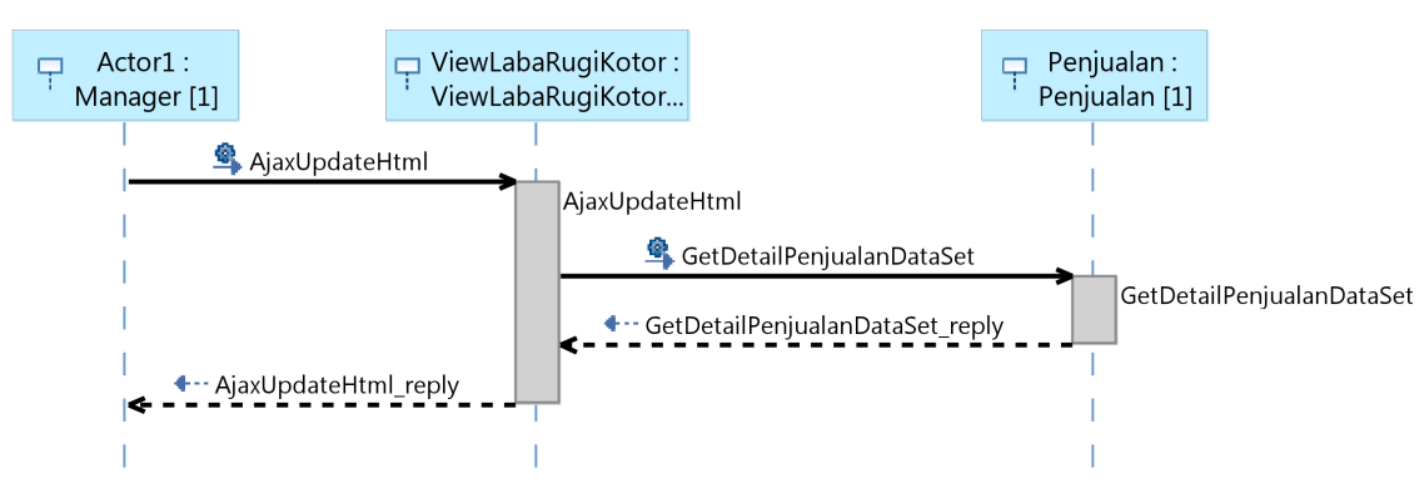

Gambar 8. Sequence Diagram Proses Menampilkan Laporan Laba-Rugi Kotor dengan AJAX.

Gambar 8 menunjukkan langkah-langkah seorang actor, yang dalam hal ini adalah seorang manager dalam menampilkan laporan laba-rugi kotor. Manager memilih periode labarugi kotor yang diinginkan, misalnya dari tanggal 01 November hingga 15 November 2017. Setelah itu sang manager akan mengklik tombol "Tampilkan" pada web mobile, yang kemudian akan men-trigger pemanggilan function AJAX: AjaxHtmlUpdate(). Fungsi AjaxHtmlUpdate() memerintahkan AJAX untuk mengakses data dari server web mobile ASP.NET, yaitu pada class ViewLabaRugiKotor. Class ViewLabaRugiKotor memiliki fungsi GetDetailPenjualanDataSet() yang dapat mengakses web service, yaitu pada class Penjualan. Selanjutnya class Penjualan pada web service akan mengakses basis data MySQL. Setelah MySQL mengembalikan data kepada web service, yaitu class Penjualan, maka class tersebut akan mengubah format data dari MySQL menjadi DataSet. Kemudian data tersebut dikirim kembali ke ASP.NET, yaitu class ViewLabaRugiKotor. Class tersebut akan mengubah lagi format DataSet menjadi format JSON, dan kemudian dikirimkan kembali kepada AJAX di sisi client.

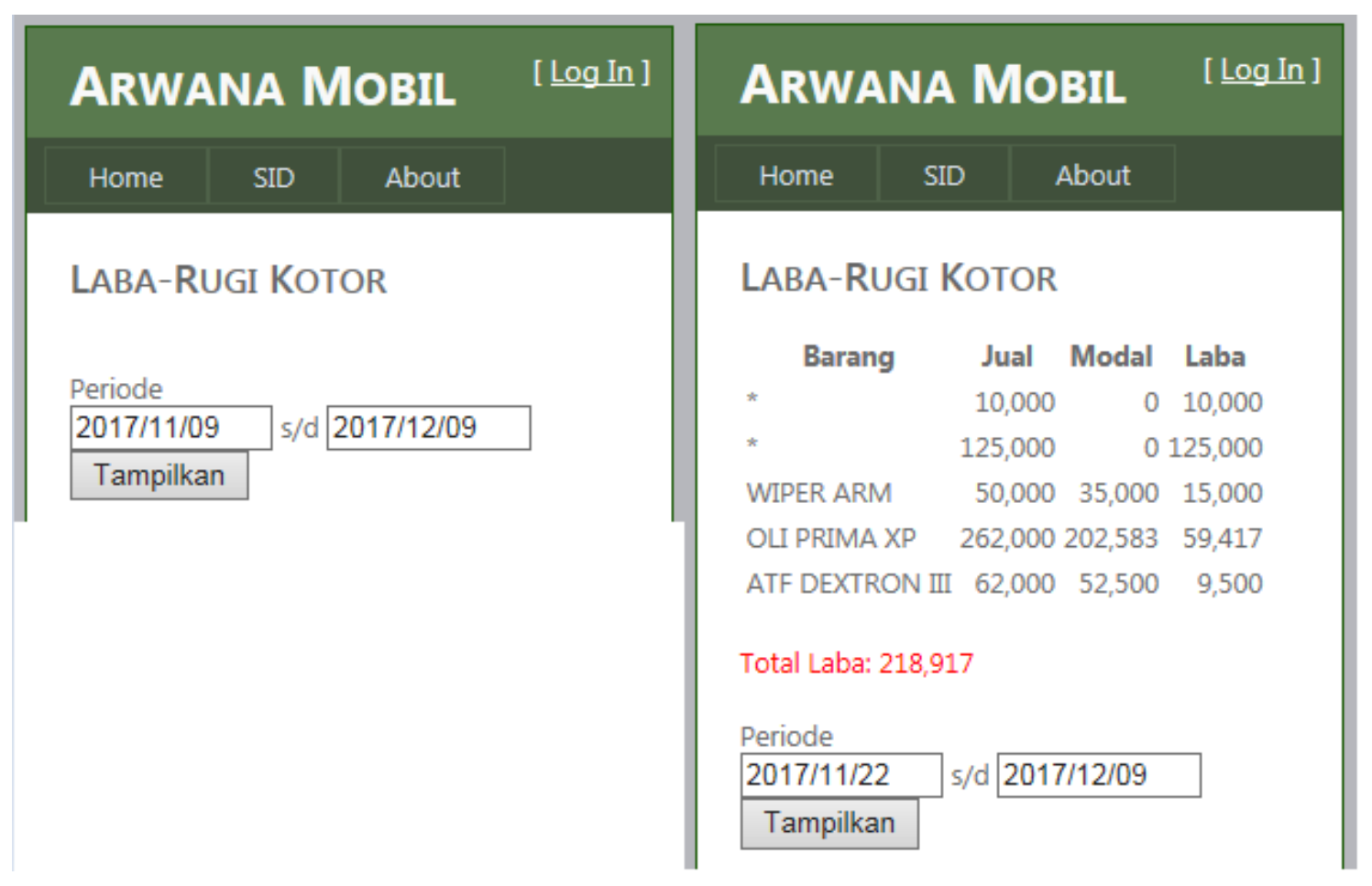

Gambar 9. Tampilan Halaman Web Laporan Laba-Rugi Kotor, Sebelum dan Sesudah

Hasil rancangan web mobile dapat dilihat pada gambar 9 seperti di bawah ini. Penulis menyajikan gambar sebelum dan sesudah menampilkan laporan laba-rugi kotor supaya dapat diketahui perbedaannya.

Untuk menguji seberapa besar efisiensi yang dihasilkan dengan penerapan AJAX di sisi 
client ini, maka penulis menyajikan tabel 2 yang berisi perbandingan sebelum dan sesudah penerapan AJAX dalam aplikasi web mobile.

Tabel 2. Perbandingan Konsumsi Bandwidth Halaman Web Biasa dengan Halaman Web AJAX.

\begin{tabular}{|l|r|r|}
\hline \multicolumn{1}{|c|}{ Keterangan bandwidth } & $\begin{array}{r}\text { Web biasa } \\
\text { (byte / ms) }\end{array}$ & $\begin{array}{r}\text { Web dengan AJAX } \\
\text { (byte / ms }\end{array}$ \\
\hline Sebelum menampilkan data & $10240 / 818$ & $10240 / 818$ \\
\hline Setelah menampilkan data (5 record) & $11980.8 / 818$ & $2464.8 / 313$ \\
\hline Setelah menampilkan data (24 record) & $17415.2 / 819$ & $7175.2 / 314$ \\
\hline Setelah menampilkan data (44 record) & $22125.6 / 820$ & $11885.6 / 315$ \\
\hline Setelah menampilkan data (75 record) & 29184 / 820 & 18944 / 315 \\
\hline Setelah menampilkan data (159 record) & $50285.6 / 822$ & $40045.6 / 317$ \\
\hline Total bandwidth (byte) & 141231.2 & 90755.2 \\
\hline
\end{tabular}

Dari percobaan sebanyak 5 kali menampilkan data pada tabel 2, dapat diketahui bahwa implementasi web biasa akan memerlukan 141.231,2 byte. Sedangkan dengan mengimplementasikan AJAX, hanya memerlukan 90.755,2 byte. Apabila dihitung, maka selisihnya adalah sebesar 50.456 byte atau dapat menghemat sebesar 35,73\% dari bandwidth website biasa. Perlu dicatat bahwa halaman web yang dirancang penulis sangat sederhana dan hanya menggunakan sampel 5 kali klik. Jadi apabila diimplementasikan pada halaman web yang memiliki lebih banyak gambar dan file-file pendukung dalam jumlah besar, maka penghematan bandwidth yang dirasakan oleh pemakai akan lebih besar lagi. Terlebih jika pemakai mengakses aplikasi tersebut dengan intensitas yang tinggi.

Variabel kedua yang dinilai pada tabel 2 adalah kecepatan muat data. Dari data tersebut dapat disimpulkan bahwa waktu muat data pertama kali tercatat sama, yaitu 818 milidetik. Akan tetapi, pada saat mulai menampilkan data, kecepatan AJAX meningkat yaitu menjadi 313 milidetik. Sedangkan pada web biasa, kecepatan muat data relatif stabil yaitu tetap 818 milidetik. Pada beberapa kali penampilan data berikutnya, waktu yang diperlukan tidak berbeda jauh. Hal ini membuktikan bahwa implementasi AJAX dapat mempercepat waktu muat data hingga $61.74 \%$. Ini merupakan angka yang sangat signifikan.

\section{KESIMPULAN}

Berdasarkan hasil perbandingan pada tabel 2, dapat disimpulkan bahwa penerapan AJAX dalam merekayasa aplikasi web mobile dapat meningkatkan efisiensi bandwidth dan kecepatan muat data secara cukup signifikan. Hal ini membuktikan penerapan AJAX sangat bermanfaat bagi pemakai sistem yaitu dapat menghemat kuota pemakaian Internet dan mempercepat proses muat data halaman web. Hal ini dikarenakan AJAX menghilangkan kebutuhan aplikasi web untuk berpindah halaman setiap kali proses penampilan data. Dengan tidak berpindah halaman, maka banyak bandwidth yang dapat dihemat karena browser tidak perlu mendownload file-file seperti HTML, CSS, JavaScript dan gambar-gambar header serta footer dari halaman web tersebut. Hanya bagian isi saja yang di-update oleh AJAX.

\section{SARAN}

Penulis menyadari bahwa penelitian ini dapat dikembangkan lebih lanjut menjadi aplikasi dengan fitur yang lebih komplit seperti sistem order untuk para sales, pelunasan piutang oleh kolektor, dan fitur-fitur lainnya. Walaupun sudah banyak aplikasi mobile yang memiliki fitur-fitur tersebut di atas, namun pada perancangannya belum menerapkan AJAX. Oleh karena itu, penulis menyarankan supaya pengembang web lainnya dapat memanfaatkan penelitian ini untuk menerapkan AJAX dalam aplikasi web mobile mereka supaya dapat memaksimalkan efisiensi bandwidth pada aplikasi mereka. 


\section{DAFTAR PUSTAKA}

[1] Kementrian Komunikasi dan Informatika, 2015, Indonesia Raksasa Teknologi Digital Asia, https://www.kominfo.go.id/content/detail/6095/indonesia-raksasa-teknologi-digitalasia/0/sorotan_media, diakses pada tanggal 13 Oktober 2017

[2] AccountingCoach, 2017, Multiple-Step Income Statement, https://www.accountingcoach.com/income-statement/explanation/4, diakses pada tanggal 4 Oktober 2017.

[3] Fritz, E., Anthony, J., Zhao, T., 2016, Arrows in Commercial Web Applications (Online), 2016 Fourth IEEE Workshop on Hot Topics in Web Systems and Technologies, DOI: 10.1109/HotWeb.2016.19, Electronic ISBN: 978-1-5090-5409-1, Print on Demand(PoD) ISBN: 978-1-5090-5410-7, 2016, Halaman 60.

[4] Sondakh, D., E., Pungus, S., R., Runtukahu, P., Saroinsong, R., 2016, Implementasi Teknologi Web Services Pada Aplikasi Pencarian Taksi (Online), Cogito Smart Journal (Universitas Klabat Manado), ISSN: 2541-2221, EISSN: 2477-8079, Volume 3, Nomor 1, 2016, Halaman 1.

[5] Pressman, R., Software Engineering : a Practitioner's Approach. Sixth Edition. McgrawHill., Singapore, 2005.

[6] N., Dr. Rajkumar, J., Selvakumar, B., Ranjith Babu, 2014, Extended Scrum Method of Agile Practice for Small Scale Project Development (Online), International Journal of Innovative Research in Science, Engineering and Technology, ISSN (Online): 2319-8753, Vol 3, Special Issue 1, Hal 374.

[7] Wikipedia, 2017, Microsoft Visual Studio, https://en.wikipedia.org/wiki/Microsoft_Visual_Studio, diakses tanggal 15 Oktober 2017.

[8] Wikipedia, 2017, ASP.NET, https://en.wikipedia.org/wiki/ASP.NET, diakses tanggal 16 Oktober 2017

[9] Microsoft Doc, 2017, What is Windows Communication Foundation, (https://docs.microsoft.com/en-us/dotnet/framework/wcf/whats-wcf, diakses tanggal 17 Oktober 2017.

[10] DevExpress, 2016, AJAX Control Tookit, https://devexpress.com/act, diakses tanggal 18 Oktober 2017.

[11] MySQL, 2017, About MySQL, https://www.mysql.com/about/, diakses 19 Oktober 2017.

[12] MySQL, 2017, MySQL Workbench, https://www.mysql.com/products/workbench/, diakses 20 Oktober 2017.

[13] Json.org, 2017, JSON, http://www.json.org, diakses tanggal 21 Oktober 2017.

[14] W3Schools, 2017, CSS Introduction, https://www.w3schools.com/css/css intro.asp, diakses tanggal 22 Oktober 2017.

[15] W3Schools, 2017, HTML \& XHTML, https://www.w3schools.com/html/html xhtml.asp, diakses tanggal 23 Oktober 2017. 